\title{
Los caballeros andantes en la obra de Feliciano de Silva: entre la tolerancia y el relativismo religioso
}

\author{
Errant knights in the Work of Feliciano de Silva: \\ Between Tolerance and Religious Relativism \\ Katarzyna Setkowicz \\ (Universidad de Wroclaw)
}

\begin{abstract}
RESUMEN
El artículo se centra en el cambio de paradigma de la materia religiosa que se realiza en las entregas del ciclo amadisiano escritas por Feliciano de Silva. En primer lugar, se describen los principios conservadores de la caballería andante seguidos en Lisuarte de Grecia y luego, a manera de contraste, todo un abanico de actitudes frente a la religión que van apareciendo a partir de Amadís de Grecia hasta la cuarta parte de Florisel de Niquea. En este contexto, entre los caballeros y las princesas surgen varias posturas que sobrepasan los límites de lo aceptable en una sociedad de cristianos viejos. El relativismo religioso caracteriza a los personajes paganos y algunos de ellos terminan bautizándose movidos por razones pragmáticas o de mayor importancia (el amor). Por otra parte, si bien es cierto que ninguno de los cristianos reniega de su fe ni se muestra disponible a hacerlo, se cometen varios errores inadmisibles: los caballeros fingen ser de otra fe, mantienen relaciones sexuales con mujeres idólatras, uno de ellos incluso comete bigamia al convivir en matrimonio con una pagana, aun sabiendo que así ofende a Dios. No obstante, el caso más considerable entre los señalados es el del ficticio autor de parte de la saga, Galersis, de quien se afirma que no solo rechaza la propuesta de convertirse, sino decide vivir hasta el final de sus días en su ley pagana.
\end{abstract}

\section{Palabras Clave}

Feliciano de Silva, libros de caballerías, tolerancia religiosa, relativismo religioso.

\begin{abstract}
The article focuses on the paradigm shift in religious matters that takes place in some of the continuations of the Amadis cycle written by Feliciano de Silva. Firstly, the conservative principles of the cavalry followed in Lisuarte de Grecia are described, and then, by way of contrast, a whole range of attitudes towards religion that appear from Amadís de Grecia to the fourth part of Florisel de Niquea. In this context, between the knights and the princesses, several positions arise that exceed the limits of what is acceptable in a society of old Christians. Religious relativism only characterizes pagan characters, and some of them end up being baptized moved by pragmatic or more critical reasons (love). On the other hand, although it is true that none of the Christians renounces their faith or is willing to do so, several unacceptable mistakes are made. The knight pretends to be of another religion, have sexual relations with idolatrous
\end{abstract}


women or commits bigamy when living in a marriage with a pagan, even knowing that it thus offends God. However, the most considerable case among those mentioned is that of the fictitious author of the saga, Galersis, about whom it is stated that he not only rejects the proposal to convert but decides to live until the end of his days in his pagan law.

\section{KEYWORDS}

Feliciano de Silva, Chivalric romances, religious toleration, religious relativism.

Recibido: 20/05/2020

Aceptado: 11/11/2020

En varios libros de caballerías españoles se respira un ambiente de tolerancia religiosa encomiable, muy diferente de la realidad que viven sus autores. Un buen ejemplo -y todo un éxito editorial (diez ediciones en tan solo cincuenta años) - sería el Lepolemo, la historia del así llamado Caballero de la Cruz, cuya sólida moral no implica la necesidad de convertir a nadie. Esa conversión habría supuesto, además, un grave problema, ya que los moros - muchos de ellos, sus amigos- se muestran tan honrados y caballerosos como cualquier cristiano, y con fuerte determinación a no renegar de su fe, salvo algunos casos concretos que se dejan convencer de la supremacía del Dios cristiano. La idealización, en tanto, concierne a los representantes de las dos religiones. Cabe subrayar que el libro se publica en Valencia, 1521, durante la rebelión de las Germanías (15191523 ), justo cuando se producen las primeras conversiones forzosas de los mudéjares.

Resulta curioso, si atendemos a los números de reimpresiones en el siglo XVI, que las historias de caballeros andantes que gozan de más estima entre los lectores de aquel entonces sean en su mayoría las que propagan la tolerancia hacia otras religiones. Aparte de Lepolemo existe, por ejemplo, el caso de los dos libros de Palmerín, otro éxito en ventas entre los libros de caballerías, donde los moros, aunque presentados como enemigos del mundo cristiano, son tratados de manera respetuosa. Eso sí, los cuatro primeros libros de Amadís de Gaula no entran en la cuenta, ya que varios aspectos de estos tomos paradigmáticos para el género los apartan de lo que viene después de su publicación.

En este artículo quiero centrarme en el ciclo más exitoso, el comenzado por Amadís de Gaula, y concretamente en las partes de la saga escritas por el prolífico Feliciano de Silva, donde incluso en ciertos momentos se puede hablar de una actitud relativista sobre el tema de la religión, aunque caracterice de manera particular el comportamiento de los personajes paganos. Ahora bien, por muy controvertido que parezca el hecho de aplicar el término de relativismo religioso en el contexto del siglo XVI, me gustaría matizar esta cuestión para claridad de este trabajo. El relativismo religioso se entiende aquí como el hecho de no afirmar que solo una religión es posible y verdadera, lo que implica también una idea de que el seguimiento de una ley concreta no sea lo más fundamental en la vida. Según señala Stuart B. Schwartz, en Cada uno en su ley: Salvación y tolerancia religiosa en el Atlántico ibérico: «La religión era una cuestión central en esta sociedad, pero, quizá, no lo era todo o, al menos, no para todo el mundo» (2010: 108). Y bien podría servir esta frase para describir la situación en el universo de la caballería andante creado por Silva. De hecho, en los libros de caballerías parece que se desvanezca la preocupación por la salvación del alma. A veces, incluso, los caballeros andantes muestran cierta desenvoltura en su interpretación de lo correcto, cayendo en los pecados más nefastos. El autor, no obstante, no los condena. Es cierto 
que, como nos demuestra Schwartz, el concepto de la herejía resulta siempre definido por las autoridades, en este caso la del propio autor ${ }^{1}$.

A lo largo del artículo no me detendré en incidir en la ya muy conocida relación de Feliciano de Silva con los judeoconversos, como Jorge de Montemayor, Alonso Núnez de Reinoso o Bernardim Ribeiro. Sin embargo, me parece importante por lo menos mencionar el hecho, ya que esta mirada pluralista seguramente tiene mucho que ver con la forma de construir el universo caballeresco en su obra. El relativismo religioso en el siglo XVI, aparte de formar parte de ciertas opiniones que nacen en el mismo seno de los cristianos viejos (Schwartz, 2010: 115), resulta también propio de los judeoconversos que, pensando en su salvación y en la de sus antepasados, tienden a buscar explicaciones sobre un destino después de la muerte.

La mayor parte de la obra de Feliciano de Silva no reproducirá el modo de pensar sobre los disidentes propagado, entre otros, por las primeras entregas del ciclo amadisiano. Puntualizo: la mayor parte, porque también hay que subrayar que la primera entrega de Silva, Lisuarte de Grecia, nos podría sugerir una actitud contraria. Eso sí, la lectura de Lisuarte de Grecia demuestra, en mi opinión, que al joven Feliciano de Silva no le interesan mucho las cuestiones religiosas. El paradigma es el derivado de las primeras partes de la obra de Montalvo (ya que no de las demasiado pías Sergas de Esplandían $)^{2}$. No solo a cada paso el autor recalca que la fe de los protagonistas es profunda e inquebrantable, sino también la misma trama resulta saturada con la idea de la lucha contra los paganos (sean llamados así o, simplemente, turcos). Esta idea sirvió para fundamentar el mensaje moralizante de la obra. Feliciano de Silva lo subraya en el prólogo, al mencionar los gloriosos hechos en armas del Conde de Niebla en Gibraltar o de Diego de Ribera en Antequera:

Que todos estos en guerras muy justas por acrescentamiento e defendimiento de la fe contra los infieles, como esforçados cavalleros recibieron la muerte dando la vida a la fama e gloria a las ánimas, con otros muchos buenos cavalleros que les tuvieron compañía (Silva, 2002: 4).

Uno de los objetivos de la caballería andante es la propagación de la fe cristiana. Por eso, cuando un caballero vence a un pagano, le plantea un ultimátum, bautizarse o morir: «Lo que nosotros queremos $[. .$.$] es que dexes essa fe mala que tienes e conozcas la verdadera que es la que en noso-$ tros creemos» (2002: 15). El vencido normalmente acepta convertirse a la fe cristiana, guiándose por un razonamiento lógico: si los caballeros cristianos han logrado vencerlo, quiere decir que su Dios es más poderoso que los suyos. Uno puede suponer que, a pesar de la coerción, la conversión es sincera, o, incluso, pragmática. Lo que explica un extraordinario fervor religioso que caracteriza a la persona recientemente convertida (sobra decir: por fuerza). El gigante a quien se le acaban de plantear los términos de rendición recién citados le informa a su mujer sobre su inminente bautizo, recurriendo a argumentos de primordial importancia:

1. El concepto de la herejía, en cuanto a su definición por parte de los autores, se encuentra, como tal, poco presente en los libros de caballerías españoles. Se podría señalar algún caso concreto, y además entre los representantes del género menos conocidos, como por ejemplo el de la Corónica de Adramón: « [Praga] a se destruydo y despoblado por las heregías poco a poco, porque toda la gente que en las montañas byve - asy grandes y señores, como el pueblo- byve en aquellas malditas heregías. Byven a su placer bestyal, y suziamente a su voluntad, porque en todas aquellas montanas no se castiga otra cosa syno rrobar o deber algo: destas II cosas se castyga y hazen justycya; todo lo demás se sufre y tyene por bueno» (1992: 46).

2. Aunque Gutiérrez Trápaga precisa: «the knight first embraces Esplandián’s values, but as the story advances, Lisuarte moves further away from this characterisation (...). Lisuarte imitated his grandfather, instead of continuing with the exclusively Christian characterisation of his father» (2017: 92-94). 
A este tiempo llegó su muger, llamada Almatrafa, e dixo:

- Argamonte, ¿cómo te sientes?

Él dixo:

- Bien, loado Dios en quien yo creo e creerán todos los que me quisieren bien de oy más.

- ¡O, Júpiter!, ¿y qué es esto? -dixo la jayana-, ¿quisiéresnos echar a perder a todos no teniendo culpa?

Él le dixo:

- Almatrafa, no te pese, que tú serás la primera que en Cristo creerás, e después de ti todos lo de la ínsula, que nadie no quede.

- ¿Por qué causa? -dixo ella.

- Yo te lo diré -dixo el jayán-. Porque después que entré en campo con estos cavalleros conoscí su Dios ser verdadero e nuestros dioses ser falsos e mentirosos, e no quieras más saber (Silva, 2002: 15).

La actividad de la caballería andante es determinada por los ideales de índole religiosa: propagación del cristianismo y destrucción de la herejía. No siempre se produce el acto de persuasión, a veces el único objetivo constituye la aniquilación del enemigo en nombre de Jesucristo. El caballero da por sentado que la misma existencia de los paganos ofende a la religión verdadera:

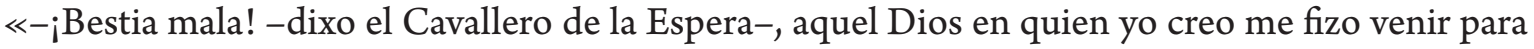
estorvar que no ofendas su santa fe» (Silva, 2002: 17). La religión no es, por tanto, sólo un aspecto secundario, sino una razón inequívoca para iniciar un combate por parte de los paganos, como de los cristianos:

Ellos nos dixeron si éramos paganos o cristianos. Nosotros respondimos que éramos cavalleros de Jesucristo y en su fe bivíamos. Oído esto por ellos, sin más dilatar, se apearon todos juntos y vinieron a nosotros con las espadas desnudas (Silva, 2002: 15).

Entre las religiones reina una tensión y un conflicto incesantes. Así como los cristianos exhiben un gran ahínco en su tarea de conversión de los paganos, de la misma manera los paganos persiguen destruir por completo la religión de sus enemigos. En una carta dirigida al emperador, la maga Melía anuncia el futuro ataque contra Constantinopla:

Yo, la infanta Melía, señora de las mágicas, enemiga de la fe cristiana, allegadora de la ley de los mis dioses [...] iré [...] sobre la ciudad de Constantinopla, y la destruiré y en su presencia en una gran foguera quemaré el escudo y amparo de toda la cristiandad. [...] Y después d'él faré lo mesmo a todos los principales de la cristiandad, e a toda la comunidad tornaré e convertiré a los mis dioses (Silva, 2002:27).

Lisuarte es un héroe predestinado para emprender una lucha en nombre de Dios, ya que nació con una marca de cruz en el pecho. Los demás caballeros andantes, aún sin señas especiales en su cuerpo, también creen ser instrumentos de la voluntad divina, cuyas espadas representan, ni más ni menos, ajusticiar a los enemigos del Altísimo. Cuando Florestán vence al rey de Breña y le parte la cabeza, dice: «Don traidor, los tales como vós assí los castiga Dios» (Silva, 2020: 31). Es más, cuando Lisuarte y Perión, junto con otros tres caballeros, defienden España ante la conquista musulmana (Lisuarte de Grecia, cap. 82-84), su repentina aparición y desaparición es interpretada como una intervención divina, parecida a la mítica batalla de Clavijo que supuestamente tuvo lugar 
durante la Reconquista y en la que intervino el apóstol Santiago. Es así como el Duque de Vizcaya interpreta la inesperada ayuda recibida de parte de los «cinco famosos cavalleros de Jesucristo»:

no penséis, según las cosas estrañas que a los dos d'ellos vi hacer, que fuessen sino Dios que vino a socorrer a los suyos. Porque ellos eran cinco cavalleros y sus armas todas coloradas como las cinco plagas que por nos Dios passó, por esto digo que creo ser él verdaderamente (Silva, 2002: 196).

Uno de los aspectos más importantes en cuanto a la actitud que presentan los cristianos en Lisuarte de Grecia, es la falta de respeto hacia los representantes de otras religiones, unida obviamente al sentimiento de superioridad religiosa. Cuando Amadís de Gaula, el Emperador de Trapisonda y la reina Calafia responden al desafío de un rey pagano Armato, lo hacen de manera abiertamente irrespetuosa, sin reparar en su dignidad real:

nuestra venida en estas partes fue a acrescentamiento e servicio de la ley de Jesucristo, en quien nosotros creemos, e para defender e destruir los enemigos de su santa fe. E comoquiera que sois reyes e de mucho merescimiento e valor, por ser enemigos de la fe no os presciamos tanto como os preciaríamos si de nuestra ley fuéssedes (Silva, 2002: 79).

Tal actitud tiene sus consecuencias a la hora de tratar con el enemigo en el tiempo de guerra. Tras una gran batalla los paganos piden a los cristianos que les den tregua por quince días, para que puedan enterrar a sus generales muertos. Aquellos, no obstante, se niegan categóricamente, lo que el rey Amadís justifica con estas palabras:

estos paganos, enemigos de Jesucristo, comoquiera que su voluntad e su venida más aya sido para ofender a Dios y enojar a este honrado emperador sobre quien han venido, que por derecho que tengan a lo que fazen, mi parecer es, pues nuestra fortuna nos ha començado a ser favorable e la suya a ellos contraria, e principalmente por ser enemigos de nuestra fe, que tregua ninguna con ellos se debe tomar [...] no se debe mostrar [a los paganos] sino lo que reina en vuestros esforçados coraçones, que es destruir estos enemigos de nuestra fe. Pues contra nuestra voluntad vinieron, no se debe hacer cosa en que se cumpla la suya (Silva, 2002: 92).

Los caballeros andantes son nobles y honrados, pero al mismo tiempo obstinados, e incluso crueles. No serán capaces de mostrar magnanimidad, ni misericordia hacia su enemigo hasta que se convierta al cristianismo, es decir, hasta que consuma una alianza con ellos. En aquel momento no se piensa en soluciones pacíficas, la caballería andante no es partidaria de reconciliación sino de aniquilación total de su enemigo:

Visto por los grandes señores cristianos el destruimiento e huida de sus contrarios, muy alegres estaban por averles dado Nuestro Señor tal victoria contra ellos; pero no quedaron muy satisfechos por no los aver todos acabado de destruir e de matar (Silva, 2002: 100).

La situación cambia, no obstante, de manera radical, varios años después, cuando Feliciano de Silva escribe otra parte de la saga. Amadís de Grecia constituye una especie de manifiesto, una 
declaración de ideas que suponen un cambio sustancial en su modo de pensar. La acumulación de tópicos o incluso enteros hilos religiosos coloca la religión en la posición de un leitmotiv y nos hace partícipes de un cambio profundo en la mentalidad del autor. Este ya no quiere enmarcarse en la ideología propuesta como paradigma de la caballería andante por Garci Rodríguez de Montalvo y otros varios autores de libros de caballerías ${ }^{3}$. Silva da una gran visibilidad a los motivos religiosos, prueba de una extraordinaria determinación en manifestar el nuevo modo de pensar. En ninguna otra parte de la saga los tópicos religiosos serán sacados a la palestra, como ocurre ya desde las primeras páginas de la obra publicada en 1530, creada en la atmósfera de escándalo y rechazo por parte de su familia que no está de acuerdo con el matrimonio de Silva con una mujer de origen judeoconverso ${ }^{4}$.

En Amadís de Grecia todos los principios religiosos de los viejos caballeros andantes son negados. En Lisuarte, los paganos se convertían en virtud de un criterio: el dios más poderoso es el que tiene a su servicio los caballeros más poderosos. Sabemos muy bien quiénes son. Nadie vencerá a los miembros del gran linaje de Amadís de Gaula. En Amadís de Grecia aparentemente no cambia nada, pero al mismo tiempo la situación sí que es muy diferente, ya que el héroe epónimo, aunque al principio lleva el nombre de Caballero de Ardiente Espada, no sólo es el mejor caballero del mundo, sino también es pagano. Tardará años (si es que se puede utilizar este concepto de tiempo en relación con los libros de caballerías) en conocer la verdad sobre sus antepasados y más años todavía en tomar la decisión de convertirse.

La nueva concepción del mundo aparece respaldada por numerosos personajes que ilustran la ruptura con el principio de la correlación de la religión politeísta con todo tipo de vicios y maldades. Ya en el primer capítulo nos encontramos ante un personaje de un rey pagano, Magadén, que cría a Amadís como si fuera su hijo:

Este rey no era de las condiciones que otros reyes, sus antepasados, por cuanto era inclinado a virtud y bien, puesto que infiel fuese y sin conoscimiento de la verdad [...]. Este rey, allende de muchas condiciones buenas que tenía, era una y la más principal no ser cruel, mas benino y piadoso, ansí con sus súbditos como con los captivos cristianos o de otras leyes que a su reino venían (Silva, 2004: 23).

El mundo de los infieles, antes repleto de maldad, soberbia y crueldad en otros libros del ciclo amadisiano y del género, ahora se llena de paganos nobles, tolerantes y magnánimos, no menos virtuosos que sus homólogos cristianos. Amadís crece en un universo pagano donde el autor le ha asegurado todas las condiciones necesarias para su desarrollo como caballero andante, junto con la aparición de un ermitaño que «en su ley por santo era tenido» (Silva, 2004: 31) y que, al pedirle Amadís un consejo, demuestra una sabiduría y bondad tal como lo haría cualquier ermitaño cristiano. De inmediato reconoce el valor del joven, augurándole un gran futuro y comparándolo, además, con los famosos caballeros andantes cristianos, sobre todo con los ilustres Amadís y Es-

3. Según señalan Sales Dasí (2002) y Gutiérrez Trápaga (2017: 85-111), Feliciano de Silva rechaza abiertamente el modelo impuesto en las asíllamadas «continuaciones heterodoxas» de Amadís de Gaula, y es justamente esta actitud contraria uno de los factores claves que lo mueve a introducir dichos motivos con tanta intensidad. Gutiérrez Trápaga lo llama incluso una «belicosa intertextualidad» (2017: 105)

4. Feliciano de Silva probablemente se casa a principios de los años 20. Sobre la relación de Feliciano de Silva con Gracia Fe y un posterior procedimiento de control genealógico que desvelará los orígenes conversos de su mujer, véase, sobre todo el artículo de Emilio Cotarelo y Mori (1926: 129-139). La presencia de los ecos de la vida privada de Feliciano de Silva en su obra ha sido ya indicada, entre otros, por Cort Daniels (1983: 77-88). 
plandián: «a quien nuestros dioses dotaron de estraña hermosura como an hecho a vós, puesto que ellos no an conocido el su poder que siempre son y an sido en abaxar la su ley y destruilla porque biven en la ley de Cristo» (Silva, 2004: 32). Viven, entonces, los caballeros andantes, equivocados en cuanto a la religión profesada, pero gracias a sus grandes hazañas han alcanzado el más alto de los estados. El prestigio es, por tanto, fruto de las acciones, y no de las creencias religiosas. Asimismo, el Caballero de la Ardiente Espada queda predestinado a alcanzar la mayor fama del mundo solo a base de sus talentos y determinación, sin importar cuál es la fe que profesa.

Así queda establecido el fundamento más importante del nuevo orden del mundo: el respeto. El comportamiento respetuoso es fruto de la virtud que con tal comportamiento se ve manifestada y demostrada. Cuando Amadís de Grecia topa en su camino con el sabio Alquife se hace clara su forma de pensar:

- Viejo honrado, ¿sabríades me decir dónde pudiesse ser curado de algunas llagas que traigo que fuese cerca de aquí?

- Si vós fuéssedes cristiano como yo -dixo el viejo-, yo os diría lo que pedís.

- Amigo -dixo él-, aunque no lo sea, lo debéis hacer, porque la virtud no se pierde doquier que se haga, pues haziéndose no puede dexar de ser virtud. Assí que si en vós la ay, ruégoos que me digáis lo que os pregunto, pues haziéndola en vós queda y no comigo; y pues sois más obligado a vós que a nadie, no dexéis de hacer bien pudiéndolo hazer, que los dioses no son estimados sino por el bien que d'ellos se espera y en ellos ay. Assí que, aunque no séais de su ley, no dexáis de semeyalles en lo bueno, que otro tanto haré yo de lo que bien me pareciere de vuestro dios aunque soy pagano, que la virtud doquiera que esté parece bien, pues por ella los hombres vemos ser estimados (Silva, 2004: 35-36).

El diálogo, hay que decirlo, carece de verosimilitud. Por un lado, porque el joven caballero dice de sí mismo «soy pagano», como si hubiera tomado el punto de vista del anciano, pero evidentemente no lo hace. Por otro, Alquife es un gran mago, conoce muy bien la historia, o incluso el futuro de Amadís, sabe también que es su deber ayudarle y entregarle una buena armadura que, dicho sea de paso, le servirá para luchar contra los caballeros cristianos. El fragmento tiene como único objetivo una clara manifestación de valores con los que a partir de ahora deben guiarse los representantes de la caballería andante. El trato misericordioso hacia una persona se convierte en un deber, independientemente de su fe. Esta filosofía la comparte un monje que se niega a indicarle a Amadís el camino hacia un castillo gobernado por el almirante Frandalo, pues el fraile cree que decírselo es como si lo mandara a una muerte segura: «aunque seáis pagano y enemigo de la fe, a los religiosos no nos es dado por ninguna vía ser causa de matar a nadie» (Silva, 2004: 39). Una frase curiosa, dada la actividad de la Iglesia por aquel entonces.

La virtud no solo debe condicionar nuestra actitud hacia el enemigo, sino al enemigo hay que estimarlo justo en vista de su virtud, que es una cualidad independiente de sus creencias religiosas. Amadís de Grecia le perdona la vida al Emperador Esplandián y les ordena a sus soldados que lo traten de manera respetuosa. Sin embargo, cuando el caballero se marche, los turcos optarán por vengarse del emperador. Esplandián, por supuesto, sale victorioso de la lucha y así es como concluye la situación experimentada:

estos traidores me querían matar sin ningún conoscimiento de bien que en ellos podía aver, que devieran tomar enxemplo en la bondad y cortesía d'esse cavallero [...] que aunque como enemigo lo desame, no dexaré de fazelle honra y placer por sus buenas mañas, 
aunque no sea por ál sino por dar buen enxemplo a los que no tienen virtud ni nobleza (Silva, 2004: 67).

Resulta muy significativo el primer encuentro entre el Caballero de la Ardiente Espada y Alpartacio, el rey de Sicilia, que a primera vista parece un personaje sacado de alguna de las partes anteriores de la saga. Alpartacio, al ver a Amadís, lo desafía a un duelo, ya que vive «contra ley de aquel soberano Señor que a todos nos crió e hizo de nada» (Silva, 2004:69). Se produce un combate en que Alpartacio pronto cae al suelo herido e inconsciente. Es, entonces, cuando se acerca una hermosa doncella y le pide a Amadís piedad para el rey vencido. El caballero accede a la petición de la mujer y le dice: «plázeme de hazer lo que me pedís porque mi costumbre es honrar las tales como vós, puesto que este cavallero me quería matar sin le aver hecho por qué » (Silva, 2004: 69). Aquí se encuentran dos mundos, dos paradigmas caballerescos. Amadís de Grecia funciona según otro credo, en su mundo de valores las diferencias religiosas no motivan el conflicto. La perspectiva de Alpartacio, compartida al fin y al cabo por los protagonistas de las partes anteriores de la saga, le resulta incomprensible al Caballero de la Ardiente Espada. Es más, la actitud de Amadís posibilita la reconciliación entre los representantes de las dos religiones, que entablan una amistad y se marchan juntos a recuperar a la mujer y a la hija de Alpartacio, las dos cautivas en las manos del cruel señor de la isla de Silanchia. El Caballero de la Ardiente Espada no siente ninguna especie de solidaridad con el malvado jayán, aun profesando la misma religión: «aunque a esos que dezís que las llevaron sean de mi ley, no dexaré de mudar sus malas mañas» (Silva, 2004: 71).

La tolerancia religiosa no desemboca en la negación de la supremacía de la religión cristiana, aunque este mensaje se transmita de manera mucho más sutil que en los casos anteriores. Al final, casi todos los personajes principales que por diferentes motivos profesan una fe politeísta son predestinados a bautizarse. Ahora bien, es un constructo argumental que permite al autor presentar los caminos de conversión justos y pacíficos. Resulta difícil imaginar que un gran caballero se convierta de manera forzada. El difícil y duradero proceso de la conversión queda reflejado en el personaje del Caballero de la Ardiente Espada. El protagonista de la obra muchas veces debate sobre su visión del mundo, gracias a lo que los lectores pueden conocer tanto los argumentos que le impiden convertirse, como apreciar el argumento definitivo, el que decidirá sobre su fe.

Este proceso viene explicado de manera muy ilustrativa, asemejándose en partes a los tratados de los erasmistas españoles. Veamos algunos ejemplos. Cuando Amadís de Grecia decide recuperar por sí solo el castillo de las manos de los cristianos, su fiel escudero Ineril intenta persuadirle de que no lo haga. No lo hace, vale subrayar, por miedo a la derrota, sino porque, dadas las circunstancias del rapto de Amadís cuando era niño, no se sabe, si es hijo de cristianos o de paganos. Según argumenta el escudero, el hijo es obligado «a seguir lo que sus progenitores siguieron». Él mismo, según nos informa en aquel momento el sabio Alquife (difícil imaginarse un nombre más árabe que este, aunque se lo presenta como cristiano), viene de linaje de cristianos y, aunque un día renegó de su fe, está pensando en volver a ella. Mas el caballero andante no acepta tal razonamiento:

Yo al presente soy pagano; el rey que me crió ansimismo lo es en la ley que desde que nací bivo; pues nunca otra tuve soy obligado a vivir y por ella morir como cualquiera buen cavallero es obligado, porque hazer otra cosa sería perder la vista teniéndola y dexar el camino sabido por el que no sé con muchos yerros que d'ellos se causan. [...] y si mas padres fueron cristianos o que no lo sean en mi mano es tener la ley que mejor fuere, que por esso 
tiene el hombre diferencia entre las bestias con la razón, que los dioses en él pusieron para escoger lo bueno y dexar lo no tal, pues tiene libre alvedrío (Silva, 2004: 40).

La defensa del libre albedrío es típica para los adversarios de las conversiones forzadas. $\mathrm{Mu}$ chos de los padres de la Iglesia, San Agustín (De gratia et libero arbitrio) entre ellos, defendían el carácter voluntario y libre del acto de la fe. El tan leído por aquel entonces Erasmo de Rotterdam llama a la paz, al diálogo y a la moderación en los actos ${ }^{5}$. Según los intelectuales erasmistas (aunque no únicamente), el que vive errando tiene que reconocer y comprender su error para poder alejarse de él. Para no buscar muy lejos, fijémonos por un momento en los escritos de un erasmista converso, Bernardo Pérez de Chinchón, un coetáneo de Feliciano de Silva. En sus Diálogos christianos contra la secta mahomética y la pertinacia de los judíos, tan solo cinco años posteriores a Amadís de Grecia, aunque no sea muy tolerante («ningun mayor mal aya agora en el mundo que la nefanda secta mahometica...» [1535: f. s/n]) manifiesta una actitud caritativa hacia los no creyentes. Eso sí, en su obra, dirigida sobre todo a la evangelización de los moriscos, se muestra del todo contrario a la idea muy difundida por aquel entonces entre los círculos convertidos (o - medio convertidos, según señala Stephen Gilman [1978: 438]):

cada uno se puede salvar en su ley: el judío en la suya, el Christiano en la suya y el Moro en la suya. Y podría ser si es verdad aquello que dicen que por esta causa cada uno tenga contentamiento en su ley y piense estar en la verdad (1535: f. s/n).

Sólo puede haber una ley verdadera, pues las religiones se contradicen en muchos aspectos y una ley divina nunca es errónea. Por lo tanto, solo el camino de Cristo lleva a la salvación. Pero el hombre, por poseer la razón y el libre albedrío debe escoger por sí mismo. Si obra virtuosamente por ser forzado a aquello, se asemeja más a una bestia que a un ser humano. Con las armas y con fuerza solo se puede convertir a las personas de manera superficial, ya que estos métodos no llevan a la convicción interna. Por eso, siempre hay que llamar a las facultades racionales. Es natural que cada uno siga la fe de su padre y el haber nacido en una fe errónea es una desgracia que hay que intentar de superar con raciocinio: «Cosa clara esta que todo hijo naturalmente ama y sigue la doctrina y criança de su padre y que todo discípulo sigue la doctrina de su maestro aunque sea falsa sino alcança razon que lo desengañe» (1535: f. s/n). Por lo tanto, Pérez de Chinchón quiere enseñar amistosamente, pretende convertir a los musulmanes demostrándoles «los errores» de su fe.

Pero no nos olvidemos de que justo por aquel entonces el problema sigue siendo vital también en los territorios españoles de ultramar. Aparecen escritos como los de Bartolomé de las Casas quien, en el mismo año de la publicación de Amadís de Grecia, redacta su De unico vocationis modo

5. Creo que uno de los pasajes más elocuentes en este contexto será el del Pretexto de la guerra contra los turcos: «[...] ni siquiera creo que se deba aprobar nuestra insistencia en hacer la guerra a los turcos. ¡Mal va la religión cristiana si su conservación depende de tales defensas! Y no es lógico que bajo tales auspicios nazcan buenos cristianos. [...] ¿Quieres atraer a los turcos hacia Cristo? No hagamos ostentación de riquezas, ni de ejército, ni de fuerzas. Que vean en nosotros no sólo el rótulo sino también los atributos auténticos del cristiano: vida intachable, deseo de hacer el bien incluso a los enemigos, paciencia inalterable frente a todas las ofensas, desprecio del dinero, indiferencia a la gloria, vida modesta. Que comprendan la doctrina celeste por su concordancia con esta forma de vida. Con tales armas se subyuga perfectamente a los turcos. [... ¿ Piensas que es hazaña de cristianos masacrar a quienes aunque a juicio nuestro son impíos, son también hombres por cuya salvación murió Cristo, [...] ? Pero supón que la suerte de la guerra nos sea favorable ¿Quién vio jamás que con la espada, la matanza, los incendios y los pillajes se produjesen verdaderos cristianos? Es menos malo ser abiertamente turco o judío que ser un cristiano hipócrita» (Erasmo de Rotterdam, 2008: 241-245). 
omnium gentium ad veram religionem [Del único modo de atraer a todos los pueblos a la verdadera religión]. El problema de la conversión de los amerindios es muy debatido en aquellos momentos. Bartolomé de las Casas refuta la violencia en la empresa evangelizadora sosteniendo que la conversión forzada sólo puede traer efectos contrarios, mientras que el credo debe de ser un acto de voluntad libre y realizado con pleno entendimiento.

Volvamos ahora a la obra de Silva. Aquí también el concepto de libre albedrío se presenta clave para una conversión verídica. El bautismo no puede ser forzado, ni con la violencia, ni con la presión social. Aunque Amadís llega a conocer a sus padres biológicos y además piensa casarse con una princesa cristiana (Luscela), se ve incapaz de tomar la decisión definitiva sobre su conversión:

Allí quedó concertado [...] que le embiasse embaxadores al rey, su padre, a pedirla por muger, a cuya causa, y de saber Amadís de Grecia sus padres ser cristianos, no sabía qué se hiziesse, y ya lo avía dicho por aquellos reyes que se devía de batizar; él lo avía dilatado diciendo que él pensaría en ello y les daría la respuesta, y a esta causa no se avía hecho (Silva, 2004: 397).

El héroe nos sirve de ejemplo por lo muy arraigada que es su fe. Sus padres son cristianos, su amada es cristiana, pero él sigue firme en sus convicciones. Faltando, eso sí, en otros aspectos al servicio a su señora. Amadís de Grecia vive en un complicado triángulo amoroso y durante toda su vida se verá desgarrado por este sentimiento prohibido hacia las dos mujeres. Cuando Luscela por casualidad se entera de la existencia de la otra mujer con la que comparte el corazón de su amado, le parece lógico que el hecho de que viva errando en cuanto a la fe le haga también errar en la materia de los amores. Si Amadís «no conoce el engaño de la ley» que profesa, entonces tampoco conoce la ley de amor según la que le debe la lealtad a Luscela. En respuesta, el caballero se pone firme:

Mi señora, no quiero consentiros nada de lo que me avéis dicho, que, si yo bivo engañado en la ley que tengo, conocido el engaño yo lo desharé, porque hasta agora no estoy yo tan informado de vuestra ley para que por solo ser mis padres d'ella me mueva, que a las baxas personas cuanto más a las altas para mudar ley les conviene mirar bien la razón (Silva, 2004: 420).

Ahora bien, está claro que en algún momento la conversión debe de llegar, pues estamos aquí ante una cosmovisión de índole tolerante, pero todavía no relativista. El autor recurre a la doctrina agustiniana de la iluminación divina. Es decir, el ser humano es capaz de conocer a Dios mediante un íntimo contacto directo, la así llamada iluminación. Es lo que experimenta Amadís (vestido de mujer, dicho sea de paso, por lo que el narrador utiliza las formas femeninas al hablar de él) al encontrarse en la, creada por magos, Torre de Universo, en cuya parte superior se representan el mundo y los cielos:

Ella quedó tan espantada de lo ver, que de cosa jamás no lo fue más, y miró en lo alto de todos los cielos y vio el carro triunfal en que el solo soberano Señor estava; luego le vino conocimiento claro del engaño que hasta allí avía tenido, y, hincando los hinojos en tierra, lo adoró renegando de los dioses que hasta allí avía tenido [...] (Silva, 2004: 459). 
La amada de Amadís no se convierte solo por haber renegado su marido de los falsos dioses. El caballero respeta sus creencias y logra convencerla con argumentos racionales. En este contexto surge otro tema importante, que hace al mundo de los libros de caballerías tan diferente al mundo que rodea a sus lectores. En el universo de la caballería andante no existe el problema de limpieza de sangre y los caballeros de ninguna manera aspiran al título de cristianos viejos - los que solo tienen descendencia cristiana sin mezcla de moro, judío o pagano. Los caballeros cristianos se enamoran de las princesas paganas y las princesas cristianas - de los caballeros paganos. $\mathrm{Al}$ final siempre el pagano cede a los ruegos de su otra mitad y se bautiza para poder tener acceso al sacramento del matrimonio cristiano. No tan reguladas, las aventuras amorosas entre paganos y cristianos se convierten en pan de cada día hasta tal punto, que empiezan a conformar la mayoría de los casos y el mundo se llena de hijos nacidos fuera del matrimonio. Incluso otrora muy conservador Lisuarte que, como bien recordamos, andaba por el mundo luchando contra los infieles, ahora, a causa de la intervención del autor, se inscribe en esta nueva tendencia. Feliciano de Silva decide hacer algo que odia hacer y que no repetirá ya nunca a lo largo de toda su obra. El autor da muerte a la muy amada mujer de Lisuarte, Onoloria, para que el rey pueda casarse con una reina pagana, Abra.

Los protagonistas de la saga siguen los pasos de su creador. Amadís de Grecia, como ya sabemos, se casa con una bella pagana, Niquea. Otros dos hijos suyos, que, junto con su hijo legítimo, Florisel, compartirán el protagonismo de la siguiente parte de la saga, nacen de una aventura amorosa de Amadís con una reina idólatra, Zahara. Alastraxerea y Anaxartes nunca conocerán la identidad de su padre, pero se considerarán hijos del dios Marte. La «inmaculada concepción» en la que participa Zahara nos hace pensar directamente en los pasajes bíblicos. Según leemos, Zahara:

[...] hizo grandes sacrificios a un ídolo suyo para que le dixesse de qué forma avía sido preñada, pues ella no podía pensar en qué forma lo estava, a la cual el ídolo respondió que le hazía saber que por su bondad y hermosura el soberano dios Mares se avía d’ella enamorado y que avía venido a ella en sueños sin lo sentir y que avía tenido parte con ella, por do supiesse que el vientre que tenía era sagrado y lo que pariesse sería del dios Mares (Silva, 2004: 558).

Aunque Florisel de Niquea al final se casa con una princesa cristiana, Helena, no olvidemos que durante muchos capítulos intenta conquistar el corazón de una pastora pagana, Silvia. Además, al querer defender a su amigo, comete una bigamia y se casa con una bella reina idólatra, Sidonia. Por su parte, el protagonista de la tercera parte de Florisel de Niquea, Agesilao, a lo largo de todo el libro lucha por el amor de la hija de Sidonia, Diana, mientras que Rogel de Grecia, en la parte cuarta, se enamora de la reina Arquisidea, considerada por sus súbditos una diosa. En todos estos casos, pero también en muchos otros que se pueden encontrar en la obra de Feliciano de Silva, el acto del bautismo tiene lugar a punto de contraer el matrimonio oficial (porque no -el secreto, que normalmente se realiza con bastante antelación), para que este pueda efectuarse según los ritos cristianos. La conversión en estos casos es tratada de manera totalmente pragmática, muy alejada de los serios ( $\mathrm{y}$ casi heréticos) dilemas que experimenta en el principio Amadís de Grecia:

Y lo que peor es no ser yo de su ley, que por esto me ha de tener en menos o me conviene dexar mis dioses haciendo a ella mi dios, y esto será perder el alma y el cuerpo. Pero como- 
quiera que avenga, nunca me arrepentiré de tener tal cuidado, que heregía sería apartar tan altos y excelentes pensamientos (Silva, 2004: 90).

Con mucha más ligereza razona la princesa Lucenia, quien se encuentra enamorada de Florarlán y no presta mucha importancia a una conversión religiosa con el objetivo de contraer matrimonio: «la diferencia de las leyes [se suplirá] con que o vós toméis la mía o yo la dexe para recebir la vuestra» (Silva, 1999: 60). Es cierto que en el caso de Arquisidea y Rogel la situación es algo diferente. La emperatriz Arquisidea, como ya hemos dicho, es considerada diosa por sus súbditos: «Y a esta causa en todo el Oriente se le han hecho solennes templos llamados de la diosa de los Arcos. Adonde cada día en sus aras se celebran diversos sacrificios a sus hermosos simulacros, o imágenes de Archisidea» (Silva, 1568: f. 10r). Por eso, cuando a la corte de Arquisidea llega la embajada griega con la proposición matrimonial de parte de Rogel, uno de los dos inconvenientes que menciona el consejero de la emperatriz es la diferencia de las leyes, ya que no le parece adecuado que ninguno de los dos abandone la suya. Arquisidea no desea dejar su trono, ni convertirse por eso responde al embajador: «si el príncipe Griego quiere tomar mi ley, y vivir en mi imperio, que yo casaré con el» (Silva, 1551: f. 25r). El amor, o quizás también los celos, vencen, no obstante, todos los obstáculos. Arquisidea se da cuenta de que no puede esperar más, porque si no el príncipe griego se casará con Sinestasia (que, dicho sea de paso, es confusamente similar a la emperatriz). Por lo que procura otra embajada, confesando a Archileo (que es el mismo Rogel de Grecia disfrazado de pastor): «por mas estado tengo yo el de su persona que el de su estado, ni el mio» (Silva, 1551: f. 84r). El amor sentido hacia una persona es más importante que su linaje o la religión que profesa. Aquí no vemos mucha diferencia entre la actitud de Lucenia y la de Arquisidea.

El acto de conversión, a su vez, será utilizado de manera oportunista por Zair y Abra quienes están enamorados de los infantes cristianos. El rey de Babilonia piensa presentarse en la corte del Emperador de Trapisonda y declarar su disposición a bautizarse a condición de que se le conceda un favor cuando ya sea cristiano. El Emperador no sabe que Zair quiere pedirle a su hija por mujer. Abra, la autora de este plan malévolo, le asegura:

Esto todo será hasta tener la princesa en nuestro poder, que después todo estará en nuestro mano hazer a nuestra voluntad, porque de otra suerte, no fingiendo tú ser cristiano, el Emperador ternía legítima causa para no darte su hija. Y para esto conviénete esta noche muy secretamente dar parte d'este hecho a todos los reyes y grandes señores que contigo an venido porque no se escandalizen en ser cristianos, pues no á de ser para más de dar fin a nuestro propósito (Silva, 2004: 274-275).

Según podemos ver, las cuestiones religiosas dejan de jugar un papel primordial, y no solo entre los paganos. Los protagonistas cristianos no dudan de hacerse pasar por infieles tanto para proteger su vida como por motivos mucho menos serios. Cuando Florisel quiere acercarse a la bella Silvia, finge ser pagano para poder de este modo entablar una conversación:

Como don Florisel salió y llegó a la fuente, sin que Silvia lo viesse se llegó, y dixo porque no fuessen tenidos por cristianos:

-Los dioses salven aquella en quien tanta parte de su poder quisieron mostrar (Silva, 2004: 571). 
En el amor, el fin justifica los medios. Así piensa tanto Florisel como Agesilao, quien en la tercera parte de Florisel de Niquea estará todo el tiempo disfrazado de mujer y, además, pagana.

Comenzando por el segundo libro de Amadís de Grecia, los representantes de otras religiones afianzan su presencia en el mundo de caballería andante y, lo que es más importante, los reyes cristianos los tratan con mucho respeto y sin prejuicios. Nadie se permite insinuar que los paganos no merezcan una consideración igual a la de las damas y los caballeros cristianos; son hospedados en las cortes cristianas en un ambiente de paz y amistad, se les rinde honores debidos a su alto estado. Incluso en el mundo de la magia los representantes de las religiones paganas se alían con los magos cristianos. La maga Zirfea, la madre de una reina pagana, Axiana (a la que los caballeros griegos apoyan en su lucha por el trono de Babilonia), visita a Alquife y Urganda para proponerles hacer paces. Junto construyen la gran Torre de Universo, en la que no solo serán encantados todos los miembros de la estirpe griega, sino también, según recordamos, será el lugar de la iluminación divina, incluyendo la conversión de la maga pagana.

Ahora bien, hemos indicado algunas actitudes que sobrepasan los límites de lo aceptable en una sociedad de cristianos viejos. El relativismo religioso solo caracteriza a los personajes paganos y algunos de ellos terminan bautizándose movidos por razones pragmáticas o de mayor importancia (por ejemplo, el caso de la princesa Lucenia). Es cierto que ninguno de los cristianos reniega de su fe ni se muestra disponible a hacerlo, aunque sí a cometer ciertos 'deslices', por utilizar un término eufemístico: fingir ser de otra fe, mantener relaciones sexuales con personas idólatras, o incluso cometer bigamia y convivir en matrimonio con una pagana. De hecho, a pesar de sentir algo de remordimientos, Florisel de Niquea no experimenta demasiada necesidad de redimirse por haber mantenido una relación con la reina Sidonia:

a don Florisel le vino a la memoria el tiempo que avía que tanto avían ofendido a Dios y a su esposa, y paresciéndole que, según la reina le amava y el contentamiento que d'ella tenía, que si allá tornasse que sería causa para jamás dexar de ofender assí a Dios y a su esposa (Silva, 2015: 433-434).

Centremos la atención, ahora, en un personaje pagano que no quiere convertirse y de hecho no lo hará nunca. No es cualquiera. Hablamos del mismísimo autor (ficticio) de la obra, el gran historiador Galersis, que puso por escrito la tercera y cuarta parte de Florisel de Niquea: «Y luego, a pedimiento de la princesa, los reyes y todos los de la insula [de Colcos] fueron baptizados, excepto Galersis, que en la ley de sus dioses quiso acabar» (Silva, 1999: 8). Por lo visto, el autor no demuestra mucha preocupación por la salvación de las almas de los personajes en la obra, lo que nos lleva a una pregunta: ¿se muestra indiferente o la da por sentada? Las conversiones nunca se realizan en consideración al más allá sino al tiempo presente. Los paganos se hacen cristianos sobre todo para poder casarse. Si volvemos al muy significativo caso de Galersis, resulta interesante que Pedro de Luján en Silves de la Selva degrade en cierto modo al cronista, como si quisiera mostrar que, al tomar aquella decisión, el sabio pagano no disfruta de la ayuda divina a la hora de testificar las hazañas de los héroes. Galersis no es ya omnisciente ni se muestra capaz de seguir todos los hechos, de lo que se hace mención varias veces a lo largo del libro.

En cambio, en el caso de la obra de Silva, la conversión no es una condición de la credibilidad o del perfeccionamiento moral del personaje. A este último uno puede llegar a través, por ejemplo, del acto de arrepentimiento como lo hacen los rusianos vencidos por fin en la última parte del ciclo. Observemos que, aunque en este caso se trata de un conflicto entre dos grandes potestades 
de diferentes credos, las cuestiones religiosas no han sido detonantes del conflicto, sino en primer lugar el amor romántico, y luego el amor filial (de los hijos que quieren vengar a sus padres). En la cuarta parte de Florisel de Niquea el tema de la conversión forzada vuelve para ser rechazado plenamente por los príncipes griegos:

lo que esta en fee, como cosa sobrenatural sobre toda razon humana, no es licito, por fuerça hazer creer sus misterios, por ser sobrenaturales. Y por esta razón embió Christo sus discipulos, como ovejas entre lobos, para predicar su Evangelio, y que sojuzgassen el mundo, al reves de los Principes humanos muriendo, y no matando. Quiero decir, que la parte de la Ley Evangelica puesta en toda virtud de ley Natural, la publicassen con las palabras, como por razon natural no puede dexar de ser admitida en todo entendimiento de razon, que la publicassen, y afirmassen con actos sobrenaturales de martirios, y muertes, no matando para que creyessen, mas morir para dar vida en testimonio y fee de la verdad (...). Assi que quanto a la parte Moral, pareceme a mi, que es justo, los Principes Christianos hazer a los Infieles guardar la Ley Evangelica, como Ministros del derecho natural de Christo, por el poder que del tienen. Mas en lo que toca a la fee, como voluntariamente se ha de recebir, y la voluntad de ninguna fuerça pueda ser constreñida, no se ha de procurar hazer fuerça, hasta ser admitido, lo que no basta para ello ninguna fuerça, si la voluntad libremente no recibe la fe que esta sobre toda razón (1568: f. 115r).

Existe una enorme diferencia entre la guerra descrita en Lisuarte de Grecia y la que se desarrolla a lo largo de todo el miniciclo de Florisel de Niquea, acabando en su última parte con la gloriosa victoria de los griegos. Estos, al ser buenos cristianos y todavía mejores caballeros, deciden mostrarse misericordiosos con los rusianos que han sobrevivido. Los dos ejércitos llegan a reconciliarse ya que el rey rusiano reconoce su culpa y la de sus padres que han iniciado una guerra injusta. Los reyes griegos no solo respetan mucho a sus enemigos, hasta tal grado, que deciden participar en ceremonias fúnebres paganas. También les ofrecen su amistad que paradójicamente surge como Fénix de las cenizas de sus amigos muertos (f. 130v), según el discurso pronunciado en nombre de todos por el rey don Falanges de Astra. Ni por un solo momento aparece el tema de la posible conversión de los rusianos, si no tomamos en cuenta la propuesta del recién convertido al cristianismo rey de Susiana, que demuestra un fervor religioso impropio de los caballeros andantes griegos.

Ahora bien, como hemos visto, a partir de la primera parte de Florisel de Niquea, el tema de la religión es relegado a un segundo plano. Las creencias y los ritos siguen formando parte del universo caballeresco, aunque, más bien, a nivel lingüístico (en las exclamaciones a los dioses) y, sobre todo, tratándose de los dioses paganos. El cambio del paradigma ha concluido. La nueva jerarquía de valores de los caballeros andantes admite cierto grado de devoción piadosa, pero nunca alcanza sus extremos ni es motivo de aversión hacia un disidente. El fervor religioso es sustituido por el fervor amoroso, hasta el extremo que podríamos llamarlo directamente «la religión del amor», pues es cierto que los caballeros andantes en vez de edificar iglesias mandan construir templos en honor a sus amadas (como lo hace Falanges de Astra) o cantan ante sus imágenes como si fueran iconos (el caso de Rogel de Grecia). El hecho de que Feliciano de Silva imponga el amor como el valor máximo en la vida (el Amor se hace el dios más poderoso) causa unos efectos sorprendentes en algunos de los personajes que muestran una escala de valores invertida: el amor es para ellos más importante que la religión, las creencias, el temor a la condena eterna. La religiosidad se paganiza y el amor se sacraliza, por lo que la religión deja de aparecer como un tema fuera del contexto de las relaciones amorosas. 


\section{Bibliografía}

Cort Daniels, Marie (1983), «Feliciano de Silva: A Sixteenth-Century Reader-Writer of Romance», en Creation and Re-creation: Experiments in Literary Form in Early Modern Spain, Newark, Delaware, Juan de la Cuesta, pp. 77-88.

CotARelo y Mori, Emilio (1926), «Nuevas noticias biográficas de Feliciano de Silva», Boletín de Real Academia Española, 13, pp. 129-139.

De las CaSAs, Bartolomé (1975), Del único modo de atraer a todos los pueblos a la verdadera religión, México, Fondo de Cultura Económica.

Gilman, Stephen (1978), La España de Fernando de Rojas: panorama intelectual y social de La Celestina, Madrid, Taurus.

Gutiérrez Trápaga, Daniel (2017), Rewritings, Sequels, and Cycles in Sixteenth-Century Castilian Romances of Chivalry: 'Aquella Inacabable Aventura', Woodbridge, Tamesis.

PÉReZ De ChInchón, Bernardo (1535), Dialogos christianos contra la secta mahometica y contra la pertinacia de los judios, Valencia, Francisco Díaz Romano.

SAles Dasí, Emilio José (2002), «Las continuaciones heterodoxas (el "Florisando" [1510] de Páez de Ribera y "Lisuarte de Grecia” [1526] de Juan Díaz) y ortodoxas (el "Lisuarte de Grecia" [1514] y el "Amadís de Grecia" [1530] de Feliciano de Silva) del "Amadís de Gaula"», Edad de Oro, 21, pp. 117-152.

Schwartz, Stuart B. (2010), Cada uno en su ley: Salvación y tolerancia religiosa en el Atlántico ibérico, Madrid, Akal.

Silva, Feliciano de (1551), Libro segundo de la quarta y gran parte de la Choronica del excelente Principe don Florisel de Niquea, Salamanca, Andrea de Portonaris.

(1568), La primera parte de la quarta parte de la chronica de Florisel de Niquea, Zaragoza, Pierrez de la Floresta.

(1999), Florisel de Niquea (Tercera Parte), ed. J. M. Lalanda, Alcalá de Henares, Centro de Estudios Cervantinos.

(2002), Lisuarte de Grecia, ed. E. Sales Dasí, Alcalá de Henares, Centro de Estudios Cervantinos.

(2004), Amadís de Grecia, ed. A. C. Bueno Serrano, C. Laspuertas Servisé, Alcalá de Henares, Centro de Estudios Cervantinos.

(2015), Florisel de Niquea (Partes I-II), ed. L. Pelligrino, M. C. Bruna, Alcalá de Henares, Universidad de Alcalá. 
